\title{
AUDITORY EVENT-RELATED P300 POTENTIALS IN RHEUMATOID ARTHRITIS PATIENTS
}

\author{
Received December 4, 2013
}

The aim of the study was to assess P300 event-related potentials (ERPs) in patients suffering from rheumatoid arthritis (RA) in relation to the duration of illness, degree of disease activity, anatomical and functional stage of the disease, pain intensity, and pain unpleasantness. The cross-sectional study included 53 women with RA (RA group; mean age $50.58 \pm 0.93$ years) and 27 healthy women (control group, C; $49.41 \pm 1.08$ years). The intensity and unpleasantness of pain were determined using a visual analog scale (VAS); the functional status was assessed using HAQ (Health Assessment Questionnaire), and the disease activity was estimated using the disease activity scale (DAS28). The P300 waves initiated by auditory stimulations according to the oddball paradigm were recorded from leads $\mathrm{Fz}$ and $\mathrm{Cz}$. There were no significant differences between the P300 latencies in both leads. At the same time, the average P300 amplitudes in both leads were found to be considerably lower $(P<0.05)$ in the RA group compared to the $\mathrm{C}$ group. Thus, there is a statistically significant amplitude difference between the P300 cognitive ERPs in RA patients and control subjects.

Keywords: P300 event-related potentials (ERPs), rheumatoid arthritis, pain intensity, pain unpleasantness, visual analog scale (VAS).

\section{INTRODUCTION}

Rheumatoid arthritis (RA) is a chronic painful condition causing progressive irreversible damage to the articular and periarticular structures, their deformation and functional impairment, cognitive and emotional difficulties, and significant reduction of the quality of life [1]. Cognitive complaints, impairment of attention, memory (especially short-term) loss, loss of spatial orientation and concentration, visuospatial alterations, and disorders of motor planning and mental flexibility are frequently observed in patients with RA [2-5]. Data obtained from simple and complex psychometric measurements in patients suffering from RA are indicative of the impact of pain on cognitive functioning and demonstrate the necessity for developing new therapeutic strategies [6-8]. Application of modern methods of functional

\footnotetext{
${ }^{1}$ Faculty of Medicine, University of Novi Sad, Clinical Center of Vojvodina, Clinic for Medical Rehabilitation, Novi Sad, Serbia.

${ }^{2}$ Faculty of Medicine, University of Belgrade, Clinic for Physical and Rehabilitation Medicine, Clinical Center of Serbia, Belgrade, Serbia.

${ }^{3}$ School of Rural Health, Monash University, Melbourne, Australia.

Correspondence should be addressed to S. Tomasevic-Todorovic

(e-mail: drtomasevic@gmail.com).
}

diagnostics demonstrated association of chronic pain with changes in the brain structures and functions in patients with RA [9, 10]. Literature data also suggest complex interaction of sensory processing, attention, and cognition with chronic painful conditions; further research on the mechanisms of pain perception and cognitive dysfunctions related to the mentioned pathology is needed $[5,11]$.

Studies on cognitive P300 potentials during of the last 20 years were rather intense and clearly indicated the importance of application in these phenomena in clinical studies. Cognitive event-related potentials (ERPs) are defined as small-amplitude phasic EEG potentials related to some cognitive events; such potentials represent a sensitive indicator of the state of higher cortical functions [12]. These potentials include a series of negative and positive waves with a wide distribution on the scalp; the respective components are marked N1, P1, N2, P2, and P3 (P300) waves. The P300 wave is an ERP usually registered within the socalled oddball experimental paradigm. It is a positive wave whose peak latency in a healthy population varies between 300 and $500 \mathrm{msec}$ after stimulation; a maximum amplitude of this potential is observed over the central and parietal regions of the cerebral cortex. 
It is believed that the P300 wave is a neuroelectrical indicator of CNS activity related to processing of new information and guidance of attention to updating the memory performance $[13,14]$.

The P300 wave is a manifestation of the CNS involvement in the processing of new information when attention is engaged in refreshing memory. It is an endogenous response to a task that is not a certain direct answer to that of the target stimulus [15]. The amplitude of this potential is associated with the scope of attention focusing on a task and with the refreshing rate of the contents of working memory. Variations in the amplitude of P300 reflect the level and quality of handling incoming information. The P300 latency is a measure of the relative duration of the evaluation process, i.e., a parameter that represents the neurophysiological correlate with the rate of the cognitive processes [15]. Components of P300 ERPs are susceptible to the effects of many factors (nature of the stimuli and a variety of biological determinants), but this does not diminish the significance and clinical application of these potentials $[14,16,17]$. The P300 ERPs were tested many times in a number of clinical conditions [18].

The aim of our study was to examine the parameters of auditory P300 potentials in RA patients in relation to the duration of illness, degree of disease activity, anatomical and functional stage of the disease, and intensity and unpleasantness of pain.

\section{METHODS}

The study involved 80 subjects who were familiar with the preliminary examination. The RA group included 53 women (mean age $50.58 \pm 0.93$ years) who fulfilled the criteria for the diagnosis of RA based on the American Rheumatology Association (ARA, 1987) statements. The $C$ (control) group consisted of 27 healthy women (age $49.41 \pm 1.08$ years) and was used to define the norms of neuropsychological and neurophysiological parameters taken into account in the tests. Each participant was provided with detailed information on how to prepare for the test and the type of applied tests and tasks.

The exclusion criteria included hearing impairment, dementia, neurological and psychiatric diseases, head trauma, use of psychoactive substances and/or antidepressants three weeks before the survey, and surgery a month before the survey.

In the RA group, the following parameters were collected: number of painful and swollen joints, intensity of pain in the joints of patients evaluated by a visual analog scale (VAS) of $0-100 \mathrm{~mm}$, degree of discomfort according to the VAS of $0-100 \mathrm{~mm}$, speed sedimentation rate, a disease activity index, anatomical stage, and functional class of patients.

Auditory P300 ERPs. Registration of auditory P300 ERPs was performed using a Medtronic set. Two $\mathrm{AgCl}$ electrodes (impendance below $5 \mathrm{k} \Omega$ ) were fixed in the $\mathrm{Fz}$ and $\mathrm{Cz}$ positions according to the standard 10-20 international system. The reference electrode was composed of two linked contacts on the mastoids, and the grounding electrode was on the subject's forearm. We used the oddball paradigm with two tones, "standard" of $90 \mathrm{~dB}$ and $1 \mathrm{kHz}$ and "unexpected" of $90 \mathrm{~dB}$ and $2 \mathrm{kHz}$, presented binaurally with randomized irregular intervals through special headsets. Subjects were instructed to ignore the standard tones and to react as quickly as possible to the unexpected tone by counting and pressing a lever set held in the dominant hand. Two hundred sixty trials with the relationship between the standard and unexpected tones of $80 \mathrm{vs}$. $20 \%$ were recorded.

Processing of ERP waves included individual visual identification of the highest positive wave within a 220-450 msec window for each lead and measurements of the amplitude and latency of P300 potentials.

Statistical Analysis. Parametric (Student's $t$-test) and nonparametric (Mann-Whitney test and $\chi^{2}$ test) tests were used to compare the distributions related to two groups. To compare three or more groups of respondents, the analysis of variance (ANOVA) and Kruskal-Wallis test were used. Correlation of continuous variables was examined by calculation of the Pearson correlation coefficients.

The software package STATISTICA 8.0 licensed from the University of Novi Sad was used.

\section{RESULTS}

The RA and $\mathrm{C}$ groups did not differ significantly from each other in relation to age, education level, or marital status $(P>0.1$ in all cases $)$.

The results of tests of functional ability of the patients (RA group) using the Health Assessment Questionnaire (HAQ) showed the average value of $0.92 \pm 0.67$, and the average disease activity (DAS28) was $4.99 \pm 0.85$ (Table 1$)$. Thirty one $(58.49 \%)$ patients had moderately active disease, while $22(41.51 \%)$ had highly active disease.

A rather high average value of the pain intensity 


\section{T a b l e 1. Values of the Estimates of Disease Activity in the RA Group}

Т а б л и ц я 1. Значення оцінок активності хвороби у паціснтів із ревматоїдним артритом

\begin{tabular}{|c|c|c|c|c|}
\hline \multicolumn{2}{|l|}{ Indices of disease activity } & \multicolumn{3}{|c|}{$\mathrm{M} \pm$ s.d. } \\
\hline \multicolumn{3}{|l|}{ Disease duration, years } & \multicolumn{2}{|c|}{$9.83 \pm 7.74$} \\
\hline \multicolumn{3}{|l|}{ Anatomical stage } & \multicolumn{2}{|c|}{$2.00 \pm 0.64$} \\
\hline \multicolumn{3}{|l|}{ Disease acitivity (DAS28) } & \multicolumn{2}{|c|}{$4.99 \pm 0.85$} \\
\hline \multicolumn{3}{|l|}{ HAQ } & \multicolumn{2}{|c|}{$0.92 \pm 0.67$} \\
\hline \multirow{2}{*}{\multicolumn{5}{|c|}{$\begin{array}{l}\text { Footnotes: means } \pm \text { s.d. are shown, DAS28 is the disease activity score } 28 \text {, HAQ is the Health Assessment Questionnaire, and VAS } \\
\text { visual analog scale }\end{array}$}} \\
\hline & & & & \\
\hline \multicolumn{5}{|c|}{ Т а б л и ц я 2. Інтенсивність та неприсмність болю, оцінювані згідно з VAS } \\
\hline 25 to 50 & 20 & 37.74 & 15 & 28.30 \\
\hline 51 to 75 & 18 & 33.96 & 14 & 26.42 \\
\hline$>75$ & 10 & 18.87 & 17 & 32.08 \\
\hline Total & 53 & 100 & 53 & 100 \\
\hline
\end{tabular}

T a b l e 3. Correlation of the P300 ERP Parameters with Indices of Disease Activity in the RA Group

Т а б л и ц я 3. Кореляції параметрів хвилі Р300 з індексами активності хвороби у паціснтів із ревматоїдним артритом

\begin{tabular}{|c|c|c|c|c|}
\hline \multirow{2}{*}{ Indices of disease activity } & \multicolumn{4}{|c|}{$\mathrm{P}$ values for the $\mathrm{P} 300$} \\
\hline & amplitude in $\mathrm{Fz}$ & latency in $\mathrm{Fz}$ & amplitude in $\mathrm{Cz}$ & latency in $\mathrm{Cz}$ \\
\hline Duration of illness & -0.17 & -0.01 & -0.15 & -0.03 \\
\hline Functional class & -0.12 & -0.32 & -0.12 & -0.30 \\
\hline DAS28 & -0.12 & -0.12 & 0.01 & -0.15 \\
\hline Unpleasantness of pain & -0.22 & -0.20 & -0.16 & -0.20 \\
\hline
\end{tabular}

Footnote: P values greater than 0.3 are shown in bold.

according to the VAS scale $(56.51 \mathrm{~mm})$ and the average pain unpleasantness of $58.11 \mathrm{~mm}$ were found (Table 1$)$. Twenty eight $(52.83 \%)$ RA patients had a pain intensity on the VAS scale greater than $50 \mathrm{~mm}$, and 31 subjects $(58.5 \%)$ manifested a strong degree of pain unpleasantness (VAS $>50 \mathrm{~mm}$ ) (Table 2).

Auditory P300 ERPs. The mean latencies of the $\mathrm{P} 300$ wave in leads $\mathrm{Fz}$ and $\mathrm{Cz}$ were $332.53 \pm 21.63$ and $331.38 \pm 23.69 \mathrm{msec}$ in the $\mathrm{C}$ group, while the respective values in the RA group were $334.74 \pm 36.54$ and $339.07 \pm 36.02 \mathrm{msec}$. There were no significant intergroup differences between the P300 latencies recorded from both $\mathrm{Fz}$ and $\mathrm{Cz}(P>0.1$ in both cases $)$.
The mean amplitudes of the examined ERP in leads $\mathrm{Fz}$ and $\mathrm{Cz}$ were $10.84 \pm 8.01$ and $9.12 \pm 6.72 \mu \mathrm{V}$ in the $\mathrm{C}$ group vs. $6.09 \pm 4.56$ and $5.41 \pm 3.27 \mu \mathrm{V}$ in the RA group, respectively. Thus, the amplitudes of auditory P300 potentials recorded within the oldball paradigm were significantly smaller in patients suffering from RA, as compared with the analogous values in healthy subjects.

Estimation of the correlation coefficients for the parameters of P300 potentials with the indices of disease activity showed statistically significant inverse correlations of the P300 latency in leads Fz and $\mathrm{Cz}$ with the functional class and intensity of 
pain by the VAS $(P<0.05$; Table 3$)$. In the group of RA patients, there was weak correlation of the P300 latency in the above leads with unpleasantness of pain $(P=0.065)$ and some trend toward correlation with the anatomical stage of RA $(P<0.1$; Table 3$)$. In this table, the coefficients of correlation between the P300 amplitudes in $\mathrm{Fz}$ and $\mathrm{Cz}$ and indices of disease activity are also shown.

\section{DISCUSSION}

Complex cognitive functions are particularly vulnerable with respect to the impact of various factors, and their dysfunction and recovery can be monitored by applying the method of ERP recording. Auditory P300 ERPs are often applied for the assessment of cognitive functions; they have sufficiently high amplitudes and long enough latency. These potentials can be registered under relatively simple experimental conditions and are reliable and reproducible [17]. The P300 latency is an indicator of the potential rate of stimulus classification, while the amplitude reflects brain activity associated with the task. It is believed that comparatively longer latencies of the P300 wave show that the stimulus evaluation time is prolonged, while lower amplitudes are related to the reduced capacity of attention that is characteristic of the painful condition $[18,19]$.

Yoldas and al. [20] compared the cognitive function in 11 patients with chronic pain and in healthy subjects and found significantly lower P300 amplitudes, but not longer latencies, compared to those in healthy subjects. These authors showed that there is a correlation between the amplitude of P300 potentials and pain intensity (myalgic total score).

Comparable results were obtained by Alagonlu et al. [22], who believed that a decline in the amplitude of the P300 potential is indicative of a noticeable cognitive dysfunction in subjects with chronic pain.

Results of the analysis of the effects of pain on the P300 ERP components are contradictory to some extent. In some studies, pain-related differences in the P300 latency were not detected [21-23], while Alagonlu et al. [20] found an increase in the latency in patients suffering from chronic pain (fibromyalgia syndrome), compared to that in healthy subjects. We found neither a significant increment nor a noticeable trend toward such a change in the average P300 latency in RA patients. At the same time, there was a clear statistically significant difference between the amplitudes of P300 waves in $\mathrm{Fz}$ and $\mathrm{Cz}$ sites in the RA and $\mathrm{C}$ groups; the respective values in the RA group were noticeably smaller than those in healthy subjects (Fig. 1). This is consistent with the findings of other authors [13, 17, 22, 23].

The obtained results of the measurement of characteristics of P300 ERPs in patients with RA should be interpreted considering a number of negative impacts on the cognitive functions under condition of this pathology. The action of these factors can be partly corrected by kinesiotherapy (improved cerebral circulation, increased "arousal," more effective consumption of oxygen, changes in the concentration of endorphins). A wide range of research on the relationship between psychological distressdepression/chronic pain and cognitive abilities in patients with RA did not give clear information in this respect [24-28]. Application of functional magnetic resonance imaging showed that the association of pain with fear and anxiety activates various brain structures, leading to the development of cognitive dysfunction [29-31]. The most intense correlation between pain and ERP P300 characteristics are manifested when recording of the latter is related to easy cognitive tasks [32].

Examination of the correlation between parameters of the P300 potentials and indices of disease activity



166
$B$

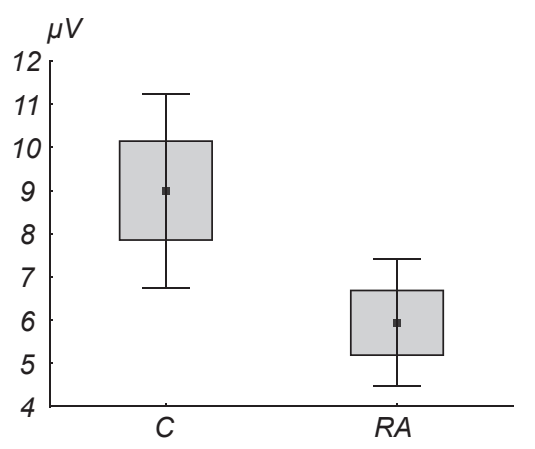

F i g. 1. Average amplitudes $(\mu \mathrm{V})$ of the $\mathrm{P} 300$ wave in leads $\mathrm{Fz}(\mathrm{A})$ and $\mathrm{Cz}(\mathrm{B})$ in the control (C) and rheumatoid arthritis (RA) groups.

Середні амплітуди потенціалів Р300 у відведеннях $\mathrm{Fz}$ (А) та $\mathrm{Cz}$ (В) у групах контролю (C) та пацієнтів із ревматоїдним артритом (RA). 
in the RA group allowed us to find a statistically significant inverse correlation between the P300 latencies with the intensity of pain by VAS $(P<0.05)$ and functional class $(P<0.05)$, which is consistent with results of the studies conducted in patients with various chronic pain conditions [22].

In the group of RA patients, we also found a negative weak correlation between the latencies of P300 potentials and pain unpleasantness estimated according to VAS $(P<0.1)$.

The studies carried out have not provided researchers with clear answers on how the cognitive mechanisms are impaired under chronic pain conditions. Therefore, further research on predictive factors with respect to cognitive dysfunction is necessary, and analysis of ERP characteristics in the respective groups may be valuable.

All testing procedures were in accordance with the ethical standards of the responsible Committees on human experimentation (institutional and national) and with the Helsinki Declaration of 1975, as revised in 2000. Written informed consent was obtained from all persons included in the study.

The authors of this study, S. Tomasevic-Todorovic, K. Boskovic, D. Filipovic, B. Milekic, M. Grajic, and F. Hanna, confirm that the research and publication of the results were not associated with any conflicts regarding commercial or financial relations, relations with organizations and/or individuals who may have been related to the study, and interrelations between co-authors of the article.

\section{С. Томашевич-Тодорович ${ }^{l}$, К. Боскович ${ }^{1}$, Д. Філіпович ${ }^{1}$, М. Граджич², Ф. Ханна}

\section{СЛУХОВІ ПОВ'ЯЗАНІ 3 ПОДІЄЮ ПОТЕНЦІАЛИ Р300 У ПАЦІЄНТІВ ІЗ РЕВМАТОЇДНИМ АРТРИТОМ}

\footnotetext{
${ }^{1}$ Університет у м. Нові Сад, Клінічний центр Воєводини, Клініка медичної реабілітації, Нові Сад (Сербія).

${ }^{2}$ Белградський університет, Клініка фізичної та реабілітаційної медицини, Клінічний центр Сербії, Белград (Сербія).
}

${ }^{3}$ Коледж охорони здоров'я неміського населення при Університеті ім. Монаша, Мельбурн (Австралія).

P е 3 ю м е

Були досліджені параметри пов'язаних із подією потенціалів (ППП) Р300 у пацієнтів, що страждають на ревматоїдний артрит (РА), та зв'язок цих параметрів із тривалістю та інтенсивністю захворювання, анатомічною та функціональною стадіями останнього, інтенсивністю та неприємністю відчуттів болю. У порівняльне дослідження були залучені 53 жінки з PA (група RA, середній вік $50.58 \pm$ \pm 0.94 року) та 27 здорових жінок (контрольна група $\mathrm{C}$, $49.41 \pm 1.08$ року). Інтенсивність та рівень неприємності болю визначали за допомогою візуальної аналогової шкали (VAS), функціональний статус - згідно 3 опитувальником HAQ, а інтенсивність хвороби - за шкалою DAS28. Потенціали Р300 ініціювали акустичною стимуляцією відповідно до oddball-парадигми та відводили від точок $\mathrm{Fz}$ та $\mathrm{Cz}$. Усереднені значення латентних періодів хвилі P300 в групах RA та C не демонстрували якихось істотних відмінностей. У той же час усереднені амплітуди Р300 в обох кортикальних зонах у групі RA були вірогідно нижчими $(P<0.05)$, ніж відповідні величини в групі С. Таким чином, існує статистично значуща різниця між характеристиками когнітивного ППП Р300 у пацієнтів із ревматоїдним артритом та здорових суб'єктів, що вказує на негативні зміни сенсорного процесінга та уваги, а також когнітивні дисфункції, виниклі під впливом хронічного болю.

\section{REFERENCES}

1. E. P. Lipsky, "Rheumatoid arthritis," in: Harrison's Principles of Internal Medicine, McGraw-Hill, New York (2001).

2. B. Dick, C. Eccleston, and G. Crombez, "Attentional functioning in fibromyalgia, rheumatoid arthritis, and musculoskeletal pain patients," Arthritis Care Res., 47, No. 6, 639-644 (2002).

3. L. Roldán-Tapia, R. Cánovas-López, J. Cimadevilla, and M. Valverde, "Cognition and perception deficits in fibromyalgia and rheumatoid arthritis," Reum. Clín. Engl., No. 3, 101-109 (2007).

4. S. Tomašević-Todorović, K. Bošković, D. Filipović, and N. Naumović, "Assessment of memory in patients with rheumatoid arthritis," Vojnosanit. Pregl., 68, No. 6, 481-488 (2011).

5. G. L. Iverson and L. M. McCracken, "Postconcussive" symptoms in persons with chronic pain," Brain Inj., 11, No. 11, 783-790 (1997).

6. S. Demirci and S. Savas, "The auditory event-related potentials in episodic and chronic pain sufferers," Eur. J. Pain, 6, No. 3, 239-244 (2002).

7. M. Ozata, Z. Odabasi, S. Caglayan, et al., "Event-related brain potentials in male hypogonadism," J. Endocrinol. Invest., 22, No. 7, 508 (1999).

8. C. Stein, A. H. Hassan, R. Przewlocki, et al., "Opioids from immunocytes interact with receptors on sensory nerves to inhibit nociception in inflammation," Proc. Natl. Acad. Sci. USA, 87, No. 15, 5935-5939 (1990).

9. R. C. Coghill, C. N. Sang, J. M. Maisog, and M. J. Iadarola, "Pain intensity processing within the human brain: a bilateral, distributed mechanism," J. Neurophysiol., 82, No. 4, 19341943 (1999).

10. R. J. Gatchel, Y. B. Peng, M. L. Peters, et al., "The biopsychosocial approach to chronic pain: scientific advances and future directions," Psychol. Bull., 133, No. 4, 581 (2007).

11. T. Pincus, J. Griffith, S. Pearce, and D. Isenberg, "Prevalence 
of self-reported depression in patients with rheumatoid arthritis," Rheumatology, 35, No. 9, 879-883 (1996).

12. J. Polich, "P300 in clinical applications: meaning, method, and measurement," Am. J. EEG Technol., 1991, available at: http:// psycnet.apa.org/?fa=main.doiLanding\&uid=1992-06110-001. Accessed June 21, 2013.

13. D. Regan, Human Brain Electrophysiology: Evoked Potentials and Evoked Magnetic Fields in Science and Medicine, Elsevier, New York (1989).

14. J. Polich, "Meta-analysis of P300 normative aging studies," Psychophysiology, 33, No. 4, 334-353 (1996).

15. J. Polich and A. Kok, "Cognitive and biological determinants of P300: An integrative review," Biol. Psychol., 41, No. 2, 103-146 (1995).

16. J. Polich and K. L. Herbst, "P300 as a clinical assay: Rationale, evaluation, and findings," Int. J. Psychophysiol., 38, No. 1, 3-19 (2000).

17. E. Donchin and M. G. Coles, "Is the P300 component a manifestation of context updating?" 1988. Available at: http:// psycnet.apa.org/?fa=main.doiLanding\&uid=1989-21502-001. Accessed June 21, 2013.

18. T. Yoldas, S. Ozgocmen, H. Yildizhan, et al., "Auditory p300 event-related potentials in fibromyalgia patients," Yonsei Med. $J ., 44$, No. 1, 89-93 (2003).

19. J. Polich, "P300 clinical utility and control of variability," $J$. Clin. Neurophysiol., 15, No. 1, 14-33 (1998).

20. E. Alagonlu, U. H. Ula, F. Ozda, et al., "Auditory event-related potentials in fibromyalgia syndrome," Rheumatol. Int., 25, No. 5, 345-349 (2005).

21. S. Ozgocmen, T. Yoldas, A. Kamanli, et al., "Auditory P300 event-related potentials and serotonin reuptake inhibitor treatment in patients with fibromyalgia," Ann. Rheumatol. Dis., 62, No. 6, 551-555 (2003).

22. S. A. Hamed, Z. I. Selim, A. M. Elattar, et al., "Assessment of biocorrelates for brain involvement in female patients with rheumatoid arthritis," Clin. Rheumatol., 31, No. 1, 123-132 (2012).
23. D. S. Veldhuijzen, J. L. Kenemans, A. J. M. Van Wijck, et al., "Processing capacity in chronic pain patients: A visual eventrelated potentials study," Pain, 2006. Available at: http://igiturarchive.library.uu.nl/phar/2007-0130-200310/veldhuijzen_06_ processingcapacity.pdf. Accessed June 21, 2013.

24. M. Hansenne, W. Pitchot, E. Pinto, et al., "P300 eventrelated brain potential and personality in depression," Eur. Psychiat., 2000. Available at: http://psycnet.apa.org/?fa=main. doiLanding\&uid=2000-02464-005. Accessed June 21, 2013.

25. P. A. Keenan, M. W. Jacobson, R. M. Soleymani, et al., "The effect on memory of chronic prednisone treatment in patients with systemic disease," Neurology, 47, No. 6, 1396-1402 (1996).

26. S. J. Linton, "Do psychological factors increase the risk for back pain in the general population in both a cross-sectional and prospective analysis?" Eur. J. Pain, 9, No. 4, 355-355 (2005).

27. M. J. Sullivan, W. Stanish, M. E. Sullivan, and D. Tripp, "Differential predictors of pain and disability in patients with whiplash injuries," Pain Res. Manag., 7, No. 2, 68 (2002).

28. P. Rainville, G. H. Duncan, D. D. Price, et al., "Pain affect encoded in human anterior cingulate but not somatosensory cortex," Science, 277 (5328), 968-971 (1997).

29. A.V. Apkarian, M. C. Bushnell, R. D. Treede, and J. K. Zubieta, "Human brain mechanisms of pain perception and regulation in health and disease," Eur. J. Pain, 9, No. 4, 463-463 (2005).

30. A. V. Apkarian, Y. Sosa, S. Sonty, et al., "Chronic back pain is associated with decreased prefrontal and thalamic gray matter density," J. Neurosci., 24, No. 46, 10410-10415 (2004).

31. S. C. Brown, J. M. Glass, and D. C. Park, "The relationship of pain and depression to cognitive function in rheumatoid arthritis patients," Pain, 2002. Available at: http://psycnet. apa.org/?fa=main.doiLanding\&uid=2002-13602-005. Accessed June 21, 2013.

32. M. E. Houlihan, P. J. McGrath, J. F. Connolly, et al., "Assessing the effect of pain on demands for attentional resources using ERPs," Int. J. Psychophysiol., 51, No. 2, 181-187 (2004). 